\title{
The Impact of Managerial Opportunism on Earnings Reliability
}

\author{
Chang Chee Fei ${ }^{1}$ \\ ${ }^{1}$ Sunway University Business School, Sunway University, Bandar Sunway, Malaysia \\ Correspondence: Chang Chee Fei, Sunway University Business School, Sunway University, No. 5, Jalan \\ Universiti, 47500 Bandar Sunway, Selangor, Malaysia. Tel: 603-7491-8622. E-mail: cfchang @ sunway.edu.my
}

Received: August 1, 2015

Accepted: August 24, 2015

Online Published: September 25, 2015

doi:10.5539/ijef.v7n10p222

URL: http://dx.doi.org/10.5539/ijef.v7n10p222

\begin{abstract}
This study is motivated by the increasing incidences of corporate failures caused by fraudulent accounting and breaches in corporate governance and ethical conducts. For example, it is expected that managers will resort to activities that are not consistent with appropriate governance and ethics just to keep up with the market expectations to safeguard their position. This study investigates the impact of five managers' opportunistic incentives on the reliability of firms' reported earnings (namely free cash flow, abnormal capital expenditure, bonus plan, distress sign and leverage), controlled by six other widely implemented standard structural governance mechanisms. The earnings reliability tests are conducted using the balanced panel data analysis specification covering 323 sample firms with continuous accounting and corporate governance data of 15 years beginning 1993. Consistent with literature, the results reveal that firms' earnings reliability is significantly related to all managerial opportunism attributes, implying the adverse effect of these incentives on the usefulness of accounting information in assessing management's stewardship. These findings suggest the need for a better management mechanism to integrate governance and effective enforcement of control requirements to mitigate managerial opportunism and hence uphold the quality of published accounting information.
\end{abstract}

Keywords: managerial opportunism, corporate governance, opportunistic behaviour, free cash flow, bonus plan, abnormal capital expenditure, distress sign, debt reliance, earnings reliability

\section{Introduction}

The impact of managerial opportunistic incentives on firm's governance environment and accounting metrics reliability is gaining more attention recently. For instance, Gompers et al. (2003) find a significant relation between capital expenditure and the corporate governance index they constructed; whereas Lee and Yeh (2004) conclude that weak corporate governance firms suffer higher risk of financial distress and thus more susceptible to economic downturn. Compensation schemes granted to employees are frequently used in the construction of governance factors and indices (e.g., Larcker et al., 2007; Gompers et al., 2003). Also, due to the increased inherent control risks, Gul and Tsui (2001) find that external auditors increase their audit fees on firms with higher amount of free cash flow. Undeniably, breaches in governance and violation to financial reporting integrity have posted a serious threat to the reliability and usefulness of accounting information in controlling and monitoring management efficacy, value judgment and safeguarding stakeholder interests.

The increasing corporate scandals involving accounting irregularities erode the 'true and fair' notion of accounting information. Under the agency view, the presence of opportunistic distortion of accounting information induced by managers' desire to achieve earnings targets has adversely affected the accounting choices and disclosures in financial reporting (Levitt, 1998; Holthausen et al., 1995; Healy et al., 1987; Healy, 1985). As firms' underlying economic performance is measured using accounting metrics, violation to the 'contracting' and 'controlling' role (Holthausen, 1990; Watts \& Zimmerman, 1990) of accounting metrics will impair the reliability and 'informational' role of these metrics.

In the context of Malaysian stock market, majority of financially distressed firms went undetected prior to the 1997-1998 crisis. It was only after this crisis, most of the financially distressed firms were identified and attributed their failures to externalities such as tough business environment, rising costs due to unexpected currency depreciation, bad debts, declined sales revenue, bad investments and aborted deals in the wake of the economic turmoil. However, the Securities Commission (SC) reveals (Star Bizweek, 2004) that external factors were only a partial explanation as there were factors within the control of managers that they failed to deliver 
upon such as management control deficiency (e.g. failure to keep proper records, poor credit control), breaches in corporate governance (e.g., overpayment for assets purchased, fictitious accounting transactions), company laws and regulations (e.g., failure to obtain shareholders approvals for large transactions, conflict of interest in related party transactions), poor enforcement of corporate governance by the regulating bodies (Radelet $\&$ Sachs, 1998; Jomo, 1998), inconsistent audit quality and breach of ethical professional practices (Chia et al., 2007; Bakar et. al, 2002).

These factors that were identified in the post-crisis period started long before the crisis in 1997 and the cumulative effect was only realised during the crisis (Shamsher \& Taufiq, 2002). Thus, this is a pertinent research issue as the reliability of accounting metrics is highly susceptible to the effectiveness of corporate governance control mechanism and managerial opportunism. Furthermore, not much has been documented in the literature on the essential relationship between governance attributes, managerial incentives and firm performance measures; this provides an opportunity for this study to fill the gap in the literature.

\section{Earnings Reliability, Managerial Opportunism and Corporate Governance}

Accrual basis accounting allows adjustments to cash basis accounting for a more relevant representation of firm financial position. However, this accounting convention is affected by management's discretion (Note 1) (Whelan \& McNamara, 2004). From the information perspective, the accrual accounting practice provides a signal to the market (Holthausen, 1990). However, if accrual accounting is used opportunistically (DeFond \& Jiambalvo, 1994; Watts \& Zimmerman, 1978), then, earnings measure might become inefficient and unreliable. The occurrence of income smoothing activities attributed to managers' opportunistic behaviour has indeed intricate the standard setting process (Healy \& Wahlen, 1999). Managers' incentive to exploit accrual basis accounting increases if they are bound to meet specific targets (Holland \& Ramsay, 2003; Dechow et al., 1996). Wild (1996) and Dechow et al. (1996) suggest that an appropriate monitoring system is essential in controlling the managerial opportunistic behaviour. Thus, the efficiency of such monitoring system shall affect the level of reliability of the accounting data.

\subsection{Incentives of Managerial Opportunism}

Prior studies show that effective enforcement of corporate governance could minimise the management opportunistic behaviour (Peasnell et al., 2005; Klein, 2002) and improve the validity of financial reports. Though effective governance as a control measure is supported by numerous archival research (e.g., Mueller, 2006, David-Friday et al., 2006, Gul \& Tsui, 2001, La Porta et al., 1998), these studies mainly focus on the organisational structure, ex-ante monitoring (e.g., investors' protection law, board and audit committee independence, board size, CEO duality), and managerial interest alignment (e.g., managerial ownership, ownership concentration). In more recent development, managerial opportunistic incentives are getting more attention due to their association with the corporate financial scandals in recent years. These incentives are induced, among other factors, by free cash flow, excessive capital expenditures, bonus plan, firm distress sign and financial leverage.

\subsubsection{Free Cash Flow}

Free cash flow is excess cash accumulated more than the firm can invest profitably. Firms with higher level of free cash flow tend to expand into non value-add investments, and such deliberate act would impede shareholder wealth and firm's future prospect. For example, Richardson (2006) concludes that the issue of over-investment is relatively common in non-financial firms with higher free cash flows. Gul and Tsui (2001) find that external auditors adjust their fees according to firm's level of free cash flow. This finding implies that free cash flow is associated with the higher inherent risk of earnings management (Jones \& Sharma, 2001) and thus resulting in higher audit efforts and fees (Gul \& Tsui, 2001). In fact, firm's cost of capital is statistically correlated to free cash flow (Velez-Pareja, 2010). Hence, the potential agency problems induced by free cash flow is critical (Opera, 2008) and detrimental to firm's overall wealth and motivate managers to practice creative earnings management practices that will directly affect the reliability of reported accounting information.

\subsubsection{Abnormal Capital Expenditures}

Consistent with market value maximisation hypothesis and the signalling theory, share prices react significantly to firm's capital expenditures announcements as the market perceives that capital spending enhances firm's ability to generate cash flows in the future (Bommel \& Vermaelen, 2003; Woolridge \& Snow, 1990; McConnell \& Muscarella, 1985). This implies that firms with stronger governance control are more inclined to invest on capital assets (Gompers et al., 2003). However, there is also a possibility that managers are inclined to over-invest in capital expenditures to inflate firm size, and thus may adversely affect firm's sustainability. 
Managers might plan to accelerate their firm's growth and boost short term earnings through mergers and acquisitions as to conceal their mismanagement and misinvestment (Giroux, 2006; Schilit, 2002). Therefore, abnormal capital spending pattern could imply managerial opportunism and this will affect the accounting earnings reliability.

\subsubsection{Bonus Plan}

The findings on how effectively share bonus plan aligns managers' and shareholders' interest are relatively inconclusive. Incentives such as employees share options and bonus plan are introduced to encourage managers to maximize shareholder's wealth and market optimism. These incentives arise from the gains managers are obtaining from exercising the options when market price is favourable. Unfortunately, bonus plan also induces management opportunism and subsequent breaches of reporting integrity (Godfrey et al., 2006; Healy et al., 1987). Godfrey et al. (2006) identify five variants of opportunistic perspectives, including "equity offering" which occurs "when managers try to manipulate the accounts in order to raise share prices to increase the total of their wealth" (p.287) and "management compensation" when managers manipulate accounts as to maximise utility from bonus schemes that are tied to accounting numbers" (p. 287). These arguments imply that bonus plan will indeed negatively affect the firm's governance and earnings reliability.

\subsubsection{Distress Sign}

The evidence of financial distress induced managerial opportunistic behaviour is well documented in several prior studies. For instance, Chen and Church (1996) find significant market's reaction to going concern opinion issued by independent external auditors, as the "issuance of a going concern opinion may increase investors' assessment of the firm's probability of financial failure" (p. 118). This finding implies that under-performed firms are likely to have overriding incentive to boost short-term earnings using aggressive accounting gimmicks to distract shareholders' and creditors' attention, and to delay potential dismissal (Koch, 2002). Inevitably, financial troubled firms manage performance to conceal their immediate distressed condition, as they believe that this adverse situation is only transitory and recovery will soon follow (Lev, 2003). Based on these anecdotes, underperforming or financially distressed firms are expected to manage their accounting information and hence adversely affects the reliability of their reported financial information.

\subsubsection{Financial Leverage}

Firms with high financial leverage are expected to be closely monitored by creditors (Godfrey et al., 2010). Thus, it is argued that the covenants set in debt agreements could effectively reduce agency problems (Gul \& Tsui, 2001; Dedman, 2000; Cotter, 1998). Under the notion of agency, debtholders are empowered to compel managers to act in their best interests through the establishment of efficient ex-ante contracting. However, it is also possible that managers of highly leveraged firm to adopt accounting procedures that enable them "to get around these covenants" (Godfrey et al., 2006, p. 311), particularly if the firm is approaching the limit of the covenants or financially distressed as a result of the increased leverage (DeFond \& Jiambalvo, 1994; Sweeney, 1994; Watts \& Zimmerman, 1990). Therefore, financial leverage could be helpful in improving the effectiveness of firms' governance control mechanism, but it could also induce managerial opportunistic behaviour.

\subsection{Corporate Governance Attributes}

Besides managerial opportunism, the standard structural governance attributes (namely firm size, ownership concentration, managerial ownership, board size, and size of audit committee and audit committee independence) are included in this study as control variables to balance their effect across the earnings reliability-managerial opportunism model specification and to maintain consistency with the prior studies. These attributes are well documented in the prior literature of corporate governance (e.g., Lin \& Hwang, 2010; Jaggi \& Leung, 2007; Lin et al., 2006; Shamsul, 2004; Kiel \& Nicholson, 2003; Maher \& Anderson, 2000). Jaggi and Leung (2007) document evidence showing the importance of audit committee in restraining earnings management, even in highly concentrated ownership firms. Furthermore, Maher and Anderson (2000) point out that diffused ownership leads to lower incentives to monitor management efficacy. Lin et al. (2006) find that the occurrence of earnings restatement is negatively correlated with the size of audit committee. Similarly, Lin and Hwang (2010) document a negative correlation between audit committee size and earnings management. Thus, it is imperative to include these standard governance attributes as control variables to ascertain the real effect of the other variables.

\subsection{Testing of Managerial Opportunism and Corporate Governance on Earnings Reliability}

Weak corporate governance induces managerial opportunistic behaviour; the catalyst of corporate malpractices and declining reliability of firm's accounting metrics. In short, ineffective governance control causes adverse 
implication on both the firm's sustainable and transitory earnings, and inaccuracy of performance forecast which subsequently can be translated into poor investment and financing decisions. To capture the impact of managerial opportunistic behavior and corporate governance on earnings reliability (Note 2), a multivariate model expressed in Equation [1] below is applied with earnings reliability as the dependent variable and multiple factors on the right side of the equation (test results from univariate regression are also included for comparison):

$$
\begin{gathered}
\text { EARNREL }_{j, t}=\beta_{0}+\beta_{1} \text { FCF }_{j, t}+\beta_{2} \text { ABCAPEX }_{j, t}+\beta_{3} \text { ESOS }_{j, t}+\beta_{4} \text { LSS }_{j, t}+\beta_{5} D E B T_{j, t} \\
+\beta_{6} \text { SZE }_{j, t}+\beta_{7} \text { OWNCON }_{j, t}+\beta_{8} \text { OWNMN }_{j, t}+\beta_{9} \text { BSZE }_{j, t} \\
+\beta_{10} \text { AUDCOM }_{j, t}+\beta_{11} \text { AUCOMIN }_{j, t}+e_{j, t}
\end{gathered}
$$

In Equation (1), $\mathrm{FCF}_{\mathrm{j}, \mathrm{t}}$ denotes free cash flow (net operating cash flow after investing and financing activities) scaled by lagged total assets. ABCAPEX $\mathrm{j}_{\mathrm{j}, \mathrm{t}}$ is the abnormal growth in capital expenditure gauged by the difference between firm j's deflated capital expenditures in year $\mathrm{t}$ and year $\mathrm{t}-1$ adjusted for the cross-sectional industry-specific ratio of capital expenditure change. This procedure captures the firm-specific capital investment growth anomalies which are anecdotally assumed to be harmful to firm's future prospects. $\mathrm{ESOS}_{\mathrm{j}, \mathrm{t}}$ is the number of outstanding share options scaled by total number of shares outstanding at year $t$ and LSS $_{\mathrm{j}, \mathrm{t}}$ is the binary indicator of financial distress ( 1 if earnings before extraordinary items is negative in the preceding year, and 0 otherwise). It is hypothesised that these managerial opportunism attributes are inversely related to earnings reliability due to the agency cost of monitoring. $\mathrm{DEBT}_{\mathrm{j}, \mathrm{t}}$ defines the leverage (debt to asset ratio) of firm $\mathrm{j}$ at year t. However, the sign of the coefficient is unknown due to contradicting prior literature. $\mathrm{SZE}_{\mathrm{j}, \mathrm{t}}$ denotes firm political exposure (Note 3) due to size. $\mathrm{OWNCON}_{\mathrm{j}, \mathrm{t}}\left(\mathrm{OWNMN}_{\mathrm{j}, \mathrm{t}}\right)$ (Note 4) denotes the shareholding interest of the top 20 shareholders (directors) scaled by the total outstanding shares.

BSZE $_{\mathrm{j}, \mathrm{t}}\left(\mathrm{AUDCOM}_{\mathrm{j}, \mathrm{t}}\right.$ ) denotes the board size (audit committee size) and AUCOMIN $\mathrm{N}_{\mathrm{j}, \mathrm{t}}$ is the log of the total number of independent on the audit committee. These three standard governance attributes indicate the strength of firm governance control and thus expected to be positively linked to earnings reliability. Equation (1) is rationalised by the anecdote that earnings reliability captures the information of management opportunistic accounting adjustments (Klein, 2002) and that the presence of strong governance control is imperative to indicate high accounting reliability. Prior studies suggest that the incident of deteriorating accounting reliability is apparently due to both the informational and opportunistic (political cost, debt and equity contracting hypotheses) (Godfrey et al., 2006; Dechow et al., 1996) manipulations of accounting accruals (e.g., Ho \& Sia, 2007, Dechow et al., 1995, Easton et al., 1992, Jones, 1991). Whereas, EARNREL $\mathrm{j}_{\mathrm{j}, \mathrm{t}}$ is the proxy of accounting earnings reliability established from Sloan's (1996) theoretical work on earnings persistency. Sloan's (1996) model gauges earnings persistency by capturing the level of earnings which corresponds to the magnitude of the accounting accruals and cash flow components as specified in Equation (2) below:

$$
\operatorname{Ear} n_{j, l}=\alpha_{0}+\alpha_{1} \operatorname{TAC} C_{, t-1}+\alpha_{2} C F Q_{, t-1}+e_{j, t}
$$

In Equation (2), Earns $\mathrm{j}_{\mathrm{j}, \mathrm{t}}$ denotes earnings after tax before extraordinary items and $\mathrm{TACC}_{\mathrm{j}, \mathrm{t}-1}$ is total accrual of firm $\mathrm{j}$ in year $\mathrm{t}-1 . \mathrm{CFO}_{\mathrm{j}, \mathrm{t}-1}$ defines firm $\mathrm{j}$ 's operating cash in year $\mathrm{t}-1$, whereas $\mathrm{e}_{\mathrm{jt}}$ is essentially the proxy of industry-specific abnormal earnings pattern. In this firm-specific time series model, the slope coefficient $\alpha 1$ and $\alpha 2$ are reported as earnings persistence (indicator of firm's sustainable earnings). In this study, Equation (2) is transformed into industry (Note 5) related cross-sectional estimation approach due to the mean reverting (Note 6) (Fama \& French, 2000) and non-random walk properties (Kothari, 2001) of accounting earnings. This approach normalises the earnings pattern by establishing the normal industry specific sustainable (persistent) earnings. All variables in Equation (2) are scaled by lagged firm's total assets to mitigate potential scale bias induced by the yearly cross-sectional approach and the use of absolute values for all the variables (Barth \& Kallapur, 1996), and to maintain endogenous consistency with the previous accounting research literature. The residuals from this OLS regression are taken to be the abnormal earnings that are connected to firm's unsystematic (both opportunistical and unintentional) factors, and do not have any bearing in the long run. These residuals (Note 7) are then inversely transformed to proxy accounting earnings reliability.

\subsection{Selection of Firms}

This study uses a balanced panel data set of 4845 firm-year observations covering 323 public listed firms with complete and continuous 15-year accounting and corporate governance data beginning from 1993 to 2007. Firms in the financial, mining, high-tech and utilities industries are excluded from the sample due to their exclusive legal, structural and reporting requirements. The significance of each of the attributes is gauged by their slope coefficients and the significance of the t-statistics (p-value) obtained from the regression. White's heteroskedasticity (White, 1980) and first-order autoregressive (AR(1)) stochastic correction process are 
deployed in the earnings reliability-opportunism/ governance regression to mitigate the group-wise heteroskedasticity in the residuals of the multivariate regressions and to account for the potential serial correlation in the residuals (Hill et al., 2001).

\section{Exploratory Statistics, Results Interpretation and Discussion}

The descriptive statistics, normality (Jarque-Bera) and multicollinearity (VIF) test results are summarised in Tables 3-1 and 3-2 below. The descriptive statistics in Table 1 reveal no severe outlier in the dataset. Except for firm size $\left(\mathrm{SZE}_{\mathrm{j}, \mathrm{t}}, \mathrm{p}=0.762\right)$, the Jarque-Bera test results show that the normality assumption is not met in other attributes. This finding is indeed expected as firms would either value (therefore practise) good governance or vice versa. The normally distributed $\mathrm{SZE}_{\mathrm{j}, \mathrm{t}}$ indicates that the sample firms are selected with an evenly distributed mix of capitalisation from different industries and listing boards.

Table 1. Descriptive statistics

\begin{tabular}{lcccccc}
\hline & Mean & Median & Maximum & Minimum & Std Dev & Jarque-Bera $p$ \\
\hline EARNREL $_{\mathrm{j}, \mathrm{t}}$ & 0.932 & 0.969 & 1.000 & -6.855 & 0.207 & $0.000^{* * *}$ \\
FCF $_{\mathrm{j}, \mathrm{t}}$ & 0.024 & 0.004 & 2.718 & -1.076 & 0.168 & $0.000^{* * *}$ \\
ABCAPEX $_{\mathrm{j}, \mathrm{t}}$ & 0.000 & 0.001 & 0.803 & -1.523 & 0.078 & $0.000^{* * *}$ \\
ESOS $_{\mathrm{j}, \mathrm{t}}$ & 0.013 & 0.000 & $0.203^{\mathrm{a}}$ & 0.000 & 0.026 & $0.000^{* * *}$ \\
LSS $_{\mathrm{j}, \mathrm{t}}$ & 0.22 & 0.000 & 1.000 & 0.000 & 0.415 & $0.000^{* * *}$ \\
DEBT $_{\mathrm{j}, \mathrm{t}}$ & 0.28 & 0.236 & $16.298^{\mathrm{e}}$ & 0.000 & 0.440 & $0.000^{* * *}$ \\
SZE $_{\mathrm{j}, \mathrm{t}}$ & 0.805 & 0.807 & 1.083 & 0.45 & 0.091 & 0.762 \\
OWNCON $_{\mathrm{j}, \mathrm{t}}$ & 0.708 & 0.729 & 1.000 & 0.176 & 0.161 & $0.000^{* * *}$ \\
OWNMN $_{\mathrm{j}, \mathrm{t}}$ & 0.282 & 0.289 & 0.989 & 0.000 & 0.242 & $0.000^{* * *}$ \\
BSZE $_{\mathrm{j}, \mathrm{t}}$ & $0.876^{\mathrm{b}}$ & 0.903 & 1.301 & 0.301 & 0.131 & $0.000^{* * *}$ \\
AUDCOM $_{\mathrm{j}, \mathrm{t}}$ & $0.499^{\mathrm{c}}$ & 0.477 & 0.845 & 0.000 & 0.140 & $0.000^{* * *}$ \\
AUCOMIN $_{\mathrm{j}, \mathrm{t}}$ & $0.393^{\mathrm{d}}$ & 0.301 & 0.845 & 0.000 & 0.151 & $0.000^{* * *}$ \\
RAWGOV $_{\mathrm{j}, \mathrm{t}}$ & 2.241 & 2.463 & 4.381 & -15.467 & 0.871 & $0.000^{* * *}$ \\
\hline
\end{tabular}

Notes. *** Significant at $1 \%$

Observations, $n=4845$

a) There are some minor outliers as usually public listed firms are allowed to issue ESOS not exceeding $10 \%$ of their total issued shares. The outliers occurred due to special approval given by SC to some sample firms to grant ESOS exceeding 10\% (e.g. 15\% to 25\%) in order for these firms to meet public spread requirement under the listing requirements or after restructuring exercises.

b) The raw mean for $\mathrm{BSZE}_{\mathrm{j}, \mathrm{t}}$ is 7.5 directors.

c) The raw mean for AUDCOM $_{\mathrm{j}, \mathrm{t}}$ is 3.2 audit committee members.

d) The raw mean for AUCOMIN $\mathrm{j}_{\mathrm{j}, \mathrm{t}}$ is 2.5 independent audit committee members.

e) This abnormal DEBT $T_{\mathrm{j}, \mathrm{t}}$ observation is due to a restructuring exercise in one of the sample firms in 2002. The said firm has suffered a massive impairment in its total assets and thus inflated the debt to asset ratio significantly.

EARNREL $_{\mathrm{j}, \mathrm{t}}=$ earnings reliability, inverse of firm $\mathrm{j}$ 's scaled abnormal earnings at year $\mathrm{t}$.

$\mathrm{FCF}_{\mathrm{j}, \mathrm{t}}=$ free cash flow of firm $\mathrm{j}$ at year $\mathrm{t}$ scaled by firm $\mathrm{j}$ 's lagged total assets.

$\mathrm{ABCAPEX}_{\mathrm{j}, \mathrm{t}}=$ firm-year abnormal growth in capital expenditure controlled for average industry capital expenditure growth.

$\mathrm{ESOS}_{\mathrm{j}, \mathrm{t}}=$ total outstanding share options scaled by firm j's total issued shares at year $\mathrm{t}$.

$\mathrm{LSS}_{\mathrm{j}, \mathrm{t}}=$ dummy indicator of financial distress at year $\mathrm{t}$.

$\mathrm{DEBT}_{\mathrm{j}, \mathrm{t}}=$ the debt to asset ratio of firm $\mathrm{j}$ at year $\mathrm{t}$.

$\mathrm{SZE}_{\mathrm{j}, \mathrm{t}}=$ firm size, $\log 1 \mathrm{mil}$ of firm j's total assets at year t.

$\mathrm{OWNCON}_{\mathrm{j}, \mathrm{t}}=$ ownership concentration, total shares held by top 20 shareholders scaled by total firm $\mathrm{j}$ 's total issued shares at year $\mathrm{t}$.

$\operatorname{OWNMN}_{\mathrm{j}, \mathrm{t}}=$ managerial ownership, total shares held by directors scaled by total firm j's total issued shares at year $\mathrm{t}$.

$\mathrm{BSZE}_{\mathrm{j}, \mathrm{t}}=$ board size, $\log$ of the number of company directors in firm $\mathrm{j}$ at year $\mathrm{t}$.

$\operatorname{AUDCOM}_{\mathrm{j}, \mathrm{t}}=\log$ of the number of audit committee members in firm $\mathrm{j}$ at year $\mathrm{t}$.

AUCOMIN $_{\mathrm{j}, \mathrm{t}}=\log$ of the number of independent audit committee members in firm $\mathrm{j}$ at year $\mathrm{t}$.

$\mathrm{RAWGOV}_{\mathrm{j}, \mathrm{t}}=$ firm $\mathrm{j}$ 's governance raw score at year $\mathrm{t}$.

Table 2 shows the statistics of the collinearity tolerance and variance inflation factors (VIF) test for the all the attributes. Except for $\mathrm{AUDCOM}_{\mathrm{j}, \mathrm{t}}$ (tolerance $\left.=0.290\right)$ and $\mathrm{AUCOMIN}_{\mathrm{j}, \mathrm{t}}$ (tolerance $\left.=0.275\right)$ the tolerances of the other 9 attributes are significantly higher than 0.8 , indicating low collinearity between these independent variables. This finding is further confirmed by the variance inflation factors (VIF) stated in table 2. Statistically, 
the VIF of $\operatorname{AUDCOM}_{\mathrm{j}, \mathrm{t}}(\mathrm{VIF}=3.450)$ and $\mathrm{AUCOMIN}_{\mathrm{j}, \mathrm{t}}(\mathrm{VIF}=3.634)$ reveals severe multicollinearity.

Table 2. Collinearity statistics-tolerances and VIF

\begin{tabular}{lcc}
\hline Model & Tolerance & VIF \\
\hline FCF $_{\mathrm{j}, \mathrm{t}}$ & 0.973 & 1.028 \\
ABCAPEX $_{\mathrm{j}, \mathrm{t}}$ & 0.990 & 1.010 \\
ESOS $_{\mathrm{j}, \mathrm{t}}$ & 0.968 & 1.033 \\
$\mathrm{LSS}_{\mathrm{j}, \mathrm{t}}$ & 0.803 & 1.245 \\
$\mathrm{DEBT}_{\mathrm{j}, \mathrm{t}}$ & 0.890 & 1.123 \\
SZE $_{\mathrm{j}, \mathrm{t}}$ & 0.864 & 1.158 \\
OWNCON $_{\mathrm{j}, \mathrm{t}}$ & 0.795 & 1.258 \\
OWNMN $_{\mathrm{j}, \mathrm{t}}$ & 0.898 & 1.114 \\
BSZE $_{\mathrm{j}, \mathrm{t}}$ & 0.816 & 1.226 \\
AUDCOM $_{\mathrm{j}, \mathrm{t}}$ & 0.290 & 3.450 \\
AUCOMIN $_{\mathrm{j}, \mathrm{t}}$ & 0.275 & 3.634 \\
\hline
\end{tabular}

Referring to Chapter 3 para 3.05 of the Listing Requirements of Bursa Malaysia (Listing Requirement), the majority of the members in the audit committee including the chairman shall be independent directors at all time. This explains the severe collinearity in $\mathrm{AUDCOM}_{\mathrm{j}, \mathrm{t}}$ and $\mathrm{AUCOMIN}_{\mathrm{j}, \mathrm{t}}$ as the number of independent directors served in the audit committee is directly proportionate to the total number of audit committee members. The test procedure then continues with the study of the association between firm's earnings reliability $\left(\right.$ EARNREL $\left._{\mathrm{j}, \mathrm{t}}\right)$ and various opportunism and governance attributes in both multivariate and univariate model and results are summarised in Table 3 below.

Table 3. Impact of governance and managerial opportunism attributes on earnings reliability-multivariate and univariate analysis

\begin{tabular}{|c|c|c|c|c|c|c|c|}
\hline \multicolumn{8}{|c|}{$\begin{aligned} \text { EARNREL }_{j, t}=\beta_{0} & +\beta_{1} \text { FCF }_{j, t}+\beta_{2} \text { ABCAPEX }_{j, t}+\beta_{3} \text { ESOS }_{j, t}+\beta_{4} \text { LSS }_{j, t}+\beta_{5} D_{E B T_{j, t}} \\
& +\beta_{6} \text { SZE }_{j, t}+\beta_{7} \text { OWNCON }_{j, t}+\beta_{8} \text { OWNMN }_{j, t}+\beta_{9} \text { BSZE }_{j, t} \\
& +\beta_{10} \text { AUDCOM }_{j, t}+\beta_{11} \text { AUCOMIN }_{j, t}+e_{j, t}\end{aligned}$} \\
\hline & \multirow{2}{*}{$\begin{array}{c}\text { Expected } \\
\text { Sign } \\
\end{array}$} & \multicolumn{3}{|c|}{ Multivariate Model } & \multicolumn{3}{|c|}{ Univariate Model } \\
\hline & & Coeff. & t-stat & $\mathrm{p}$ & Coeff. & t-stat & $\mathrm{p}$ \\
\hline$F C F_{j, t}$ & -ve & -0.047 & -5.762 & $0.000 * * *$ & -0.042 & -5.196 & $0.000 * * *$ \\
\hline$A B C A P E X_{j, t}$ & -ve & -0.016 & -1.965 & $0.050 * *$ & -0.012 & -2.144 & $0.032 * *$ \\
\hline $\operatorname{ESOS}_{j, t}$ & -ve & -0.029 & -1.651 & $0.099 *$ & -0.022 & -0.931 & 0.352 \\
\hline$L S S_{j, t}$ & -ve & -0.026 & -6.575 & $0.000 * * *$ & -0.031 & -7.783 & $0.000 * * *$ \\
\hline$D E B T_{j, t}$ & $?$ & -0.037 & -5.100 & $0.000 * * *$ & -0.041 & -5.909 & $0.000 * * *$ \\
\hline$S Z E_{j, t}$ & $+\mathrm{ve}$ & 0.080 & 1.338 & 0.181 & 0.067 & 1.069 & 0.285 \\
\hline $\operatorname{OWNCON}_{j, t}$ & $+\mathrm{ve}$ & 0.010 & 1.091 & 0.275 & 0.036 & 3.532 & $0.000 * * *$ \\
\hline$O W N M N_{j, t}$ & $+\mathrm{ve}$ & -0.003 & -0.819 & 0.413 & 0.011 & 2.461 & $0.014 * * *$ \\
\hline$B S Z E_{j, t}$ & $+\mathrm{ve}$ & 0.029 & 3.605 & $0.000 * * *$ & 0.041 & 6.419 & $0.000 * * *$ \\
\hline$A U D C O M_{j, t}$ & $+\mathrm{ve}$ & 0.026 & 1.579 & 0.114 & 0.004 & 0.405 & 0.686 \\
\hline $\operatorname{AUCOMIN}_{j, t}$ & $+\mathrm{ve}$ & -0.030 & -2.115 & $0.035^{* *}$ & -0.008 & -0.862 & 0.389 \\
\hline Observations, $\mathrm{n}$ & \multicolumn{7}{|c|}{4,522} \\
\hline $\operatorname{Adj} R^{2}$ & \multicolumn{7}{|c|}{0.174} \\
\hline F-stat & \multicolumn{7}{|c|}{3.946} \\
\hline $\mathrm{P}$ & \multicolumn{7}{|c|}{$0.000^{* * * *}$} \\
\hline Durbin-Watson & \multicolumn{7}{|c|}{2.074} \\
\hline
\end{tabular}

The test statistics in Table 3 indicate that earnings reliability is negatively correlated to the amount of free cash flow held by the firms. The coefficients of $\mathrm{FCF}_{\mathrm{j}, \mathrm{t}}$ are both significant at $1 \%$ level in the multivariate $\left(\beta_{1}=-0.047\right.$, $\mathrm{p}=0.000)$ and univariate $\left(\delta_{1}=-0.042, \mathrm{p}=0.000\right)$ test. This shows that the higher the amount of free cash flow 
retained by a firm, the higher the tendency of the occurrence of management opportunistic behaviour, and thus deteriorating the reliability of the firm's accounting earnings. This result is indeed consistent with Jones and Sharma's (2001) finding on the significant association between discretionary accrual and free cash flow of firms in the "old economy sector". This indicates that free cash flow is a catalyst for earnings management and a potential sign of poor governance. It increases monitoring cost and adversely affects accounting earnings reliability. Anecdotally, firms are supposed to keep lower amount of free cash flow as managers are more conservative in their accounting choices on loss recognition especially in the period of negative cash flow (Ball \& Shivakumar, 2005) and are compelled to instigate corrective actions (Whitaker, 1999).

As both over and under investment may harm firm's future prospects, abnormal capital expenditure indicates the firm-specific capital investment policy which highlights the contradiction between stewardship and management opportunism. The results in Table 3-3 indicate a significant negative correlation between firm's earnings reliability and $\mathrm{ABCAPEX}_{\mathrm{j}, \mathrm{t}}(\beta 2=-0.016, \mathrm{p}=0.050 ; \delta 1=-0.012, \mathrm{p}=0.032)$. This implies that the perceived earnings management risk is increasing (thus decreasing earnings reliability) in tandem with the magnitude of abnormal capital expenditure growth. Anecdotally, high capital spending signifies depleting firm's free cash flow and this could eventually be translated into greater reliability of accounting earnings (consistently with the free cash flow hypothesis discussed above) for efficient market pricing. However, Schilit (2002) and Giroux (2006) find numerous corporate scandals in US involving firms that engaged into capital expansion and acquisition in order "turbocharge their growth", "rolling up unprofitable" subsidiaries and "shifting losses to a stub period" (Schilit, 2002, p. 209).

Likewise, Titman et al. (2003) find that the negative abnormal capital expenditure -return relationship is "stronger for firms with higher cash flows or/ and lower debt ratios, which probably have a greater tendency to over-invest" (p. 27). Growth in capital expenditure is taken positively by investors in general as firms' expansion projects are expected to yield positive rate of returns (Godfrey at el., 2006) and consequently reduces future capital cost (Xing, 2002). However, in the absence of worthwhile investment opportunity, the market reacts negatively to such growth (Chen et al., 2001). Intuitively, abnormal growth in capital investment might be seen as a sign of potential breach of accounting and governance control and managerial opportunism (Schilit, 2002). Nonetheless, the negative coefficients from both the multivariate and univariate specifications signify the positive effect of capital expenditure contraction on monitoring cost and earnings reliability as Ball and Shivakurma (2005) mention that "governance is affected because timely loss recognition makes managers less likely to make investments they expect ex-ante to be negative-NPV (net present value)" (p. 84).

The results in Table 3-3 indicate a modestly significant negative correlation between firm's earnings reliability and bonus plan $\left(\operatorname{ESOS}_{\mathrm{j}, \mathrm{t}}\right)$ in the multivariate $\left(\beta_{3}=-0.092, \mathrm{p}=0.099\right)$ test but not in the univariate $\left(\delta_{1}=-0.022, \mathrm{p}\right.$ $=0.352$ ) test. These test results could be due to two reasons. Firstly, the concept of using ESOS to align managers' interest with shareholder wealth maximisation goal is not highly popular within the sample firms in this study (Note 8). Secondly, the size of the ESOS granted to employees is relatively small to the size of the paid-up capital (Note 9). However, the modest evidence from the multivariate on the impact of ESOS on firms' earnings reliability does reflect managers' opportunistical incentives to breach accounting and governance control and inclination to actions aimed at maximising their own bonus payout. This is consistent with the findings of some prior studies (Bartov \& Mohanram, 2004; Healy, 1985) which document evidence on managers' opportunistic behaviour of boosting current earnings performance to maximise their ESOS gains, or to defer their ESOS benefits when the stock market condition is unfavourable.

Likewise, the results from the multivariate $\left(\beta_{4}=-0.026, \mathrm{p}=0.000\right)$ and univariate $\left(\delta_{1}=-0.031, \mathrm{p}=0.000\right)$ regression reveal a significant negative correlation between firm's earnings reliability and accounting distress sign. Godfrey et al. (2006) suggests that "an agency/ contracting argument arises when managers of poorly performing firms manipulate reported accounting figures to avoid debt covenant violation" (p. 273). Elsewhere, Dechow and Dichev (2002) argue that "losses are indicative of severe negative shocks in the firm's operating environment" and "accruals made in response to such shocks are likely to involve substantial estimation error" (p. 47).Therefore, the accounting earnings reported by poorly performing firms are perceived to contain more 'noise' (accounting manipulation) than firms with good financial health. In short, the prior literature suggests that the market connects distress sign with managers' opportunistical incentives to breach accounting and governance requirements to intentionally conceal firms' immediate poor economic performances which deemed to be transitory and recoverable soon (Lev, 2003).

As for financial leverage, the test results in Table 3-3 support the debt hypothesis, invoking the cynical role of debt covenants in promoting breach of governance and earnings manipulation. Firms' earnings reliability is found to be negatively associated with $\mathrm{DEBT}_{\mathrm{j}, \mathrm{t}}$ in both the multivariate $\left(\beta_{5}=-0.037, \mathrm{p}=0.000\right)$ and univariate 
$\left(\delta_{1}=-0.041, \mathrm{p}=0.000\right)$ regression and the findings are significant at $1 \%$ level. This implies that the integrity of financial reporting is inversely related to firm's debt to equity ratio. These findings imply that the existence of debt covenants will indeed create opportunistic incentives for managers "to adopt accounting procedures that enable them to get around these covenants" (Godfrey et al., 2006, p. 311), particularly if firm is approaching the limit of the covenants or financially distress due to leverage increase (Sweeney, 1994; DeFond \& Jiambalvo, 1994; Watts \& Zimmerman, 1990).

Whereas for the other standard corporate governance attributes, inferences drawn from the empirical results are generally consistent with prior literature for $\mathrm{BSZE}_{\mathrm{j}, \mathrm{t}}\left(\beta_{9}=0.029, \mathrm{p}=0.000 ; \delta_{1}=0.041 \mathrm{p}=0.000\right)$ (Xie et al., 2003), OWNCON $N_{\mathrm{j}, \mathrm{t}}\left(\delta_{1}=0.036 \mathrm{p}=0.000\right)$ (Fleming et al., 2005; La Porta et al., 1998) and $\mathrm{OWNMN}_{\mathrm{j}, \mathrm{t}}\left(\delta_{1}=\right.$ $0.011 \mathrm{p}=0.014)(\mathrm{Kim} \& \mathrm{Yi}, 2005$; Gul et al., 2003), implying that these attributes are statistically significant to the quality of firms' accounting measures (Note 10) Counter-intuitive observations are captured in $\mathrm{SZE}_{\mathrm{j}, \mathrm{t}}\left(\beta_{6}=\right.$ $\left.0.080, \mathrm{p}=0.181 ; \delta_{1}=0.067, \mathrm{p}=0.285\right), \operatorname{AUDCOM}_{\mathrm{j}, \mathrm{t}}\left(\beta_{10}=0.026, \mathrm{p}=0.114 ; \delta_{1}=0.004, \mathrm{p}=0.686\right)$ and $\operatorname{AUCOMIN}_{\mathrm{j}, \mathrm{t}}\left(\delta_{1}=-0.008, \mathrm{p}=0.389\right)$ (Note 11). Firm size is insignificant to earnings reliability and this observation contradicts the political hypothesis under the agency view. The plausible explanations are; 1) the explanatory power of this variable is relative low as compared to other governance attributes, and 2) the scaling procedure has somehow neutralised its predictive power. The first presumption is consistent with Xie et al. (2003) who find that firm size is redundant in the presence of other more influential governance attributes such as board size, blockholders and outside directors.

Likewise, the results show that the size of audit committee is not a guarantee of firm's earnings reliability. This finding is indeed similar to Turley and Zaman (2004) and Peasnell et al. (2005). They find no evidence that the mere existence of audit committee affects the extent of earnings management and suggest that the effectiveness of audit committees should be assessed from the perspective of their quality, experience, independence and modes of operation in future research. Theoretically, high level of the audit committee independence signifies high level of monitoring efforts (Ryan \& Wiggins, 2004), and consequently deters opportunistic incentives to manage accounting performances.

However, the empirical results tabulated in Table 3-3 reveal otherwise. In this study, audit committee independence is found to be insignificant to the reliability of accounting earnings. This observation is consistent with the overall conclusion of Owens-Jackson et al. (2009) which state that even a "fully independent audit committee does not totally eliminate fraudulent financial reporting" (p. 62), though the likelihood of fraud is reduced by committee members independence. In addition, the governance structure of a firm may not be effectively reinforced in the presence of high audit committee independence if opportunistic compensation scheme is deployed (as documented in the regression test on ESOS $_{\mathrm{j}, \mathrm{t}}$ above). Bédard et al., 2004 find that the amount of short-term equity-based compensation granted to independent audit committee members will in turn increase opportunistic income smoothing activities. This indeed set forth another argument that inappropriate compensation scheme may induce cronyism among the inside and outside directors, and therefore tarnish the trustworthiness of independent board members (Brick et al., 2005).

\section{Conclusion and Recommendation}

The corporate scandals in the past decade are substantially attributed to ex-ante management and governance control deficiency, and ex-post managerial opportunism. Due to the difficulty in detecting income-smoothing activities initiated by managers, firms' corporate governance structure is expected to curb or at least mitigate opportunistical behaviour, and as such shall indirectly improve the reliability of accounting metrics. Generally, the existence of strong corporate governance is perceived to be positively linked to financial reporting reliability and management's integrity. Thus, this study aims to assess the effect of managerial opportunism incentives and corporate governance practices on the reliability of the accounting information released by the public listed firms in Malaysia. The results reported reveal that, in general, opportunistic incentives and governance mechanism are significant to the reliability of accounting metrics. Anecdotally, free cash flow induces abnormal capital spending which will then adversely impact firm's long term prospect. Consequently, managers are likely to make opportunistic discretionary adjustments on firm's accounting metrics to conceal their under-performing capital investments.

Likewise, this study reveals that bonus plan involving stock options is indeed detrimental to the quality of firm's financial information. Many public listed firms offer bonuses and stock options based on accounting metrics and firms' market value appreciation. Thus, managers are lured into taking aggressive accounting choices to boost stock prices deliberately and eventually their own wealth by exercising the options granted. Furthermore, managers' behavior is easily affected by rewards and potential punishments attributed to their work performance. 
In many instances, underperforming managers are threatened with perks reduction or even layoffs, and they are hence induced to deploy counter tactics defensively. Thus, the appearance of financial distress is likely to push managers to manipulate accounting measures to safeguard their position, especially if their firm is on the verge of breaching the debt covenants sanctioned by lenders. This anecdote is supported by the significant negative association between firms' earnings reliability and financial distress sign/ leverage. The findings also indicated the importance of some standard corporate governance attributes in affecting the reliability of firms' accounting metrics. For instance, board size, ownership concentration and managerial ownership are statistically significant to earnings reliability and thus are perceived to be important indicators of firms' high accounting quality. The firm size, audit committee size and composition were found to be not significant variables in explaining earnings reliability.

The insights of the findings suggest the need for integration of governance and managerial opportunism control from the perspectives of ex-ante efficient contracting and price protection into firms' long term operating and human capital strategies, as the impact of these attributes on the reliability of accounting information content and market pricing decisions are statistically profound. Regulators who seek to reform the corporate governance systems or develop new regulations in upholding more ethical business practices and meaningful performance measures should clearly acknowledge the impact of opportunistic behaviour and governance control mechanism on the reliability of accounting metrics. For instance, the Sarbanes-Oxley Act 2002 (SOX) is enacted to enhance the standards for the management and boards of the public listed firms in US, as well as the professional codes of conduct for public accounting firms, auditors and securities analysts after the Enron and WorldCom scandals. Whereas in Malaysia, these reforms include the establishment of Malaysian Code of Corporate Governance (MCCG), changes in the existing rules and regulations in relation to related party transactions, new listing requirements and adoption of fair value accounting convention after the ASEAN 1997-1998 and 2008 financial calamities. These actions denote that unscrupulous management practices have drawn significant attention from the investors and regulators of the capital market. Moreover, this study substantiates the much needed empirical evidence revealing how potential management malpractices might subsequently affect the reliability of accounting metrics.

\section{Acknowledgments}

The author would like to thank Associate Professor Taufiq Hassan Shah Chowdury and Professor Zulkarnain Muhamad Sori for their invaluable guidance and assistance. The author also wishes to express his deepest gratitude to Professor Shamsher Mohamad Ramadilli Mohd for the insightful comments and support Professor Shamsher has provided, and his valuable time spent reading and correcting the drafts of this research paper.

\section{References}

Bakar, M. A., Mohamed Saat, M., \& Abdul Majid, A. (2003). Ethics and the accounting profession in Malaysia. Journal of Financial Reporting and Accounting, 1(1), 105-122. http://dx.doi.org/10.1108/19852510380000502

Ball, R., \& Shivakumar, L. (2005). Earnings quality in U.K. private firms: Comparative loss recognition timeliness. Journal of Accounting and Economics, 39(1), 83-128. http://dx.doi.org/10.1016/j.jacceco.2004.04.001

Barth, M., \& Kallapur, S. (1996). The effects of cross-sectional scale differences on regression results in empirical accounting research. Contemporary Accounting Research, 13(2), 527-567. http://dx.doi.org/10.1111/j.1911-3846.1996.tb00514.x

Bartov, E., \& Mohanram, P. (2004). Private information, earnings manipulations, and executive stock-option exercises. The Accounting Review, 79(4), 889-920. http://dx.doi.org/10.2308/accr.2004.79.4.889

Bédard, J., Chtourou, S. M., \& Courteau, L. (2004). The effect of audit committee expertise, Independence, activity on aggressive earnings management. Auditing: A Journal of Practice \& Theory, 23(2), 13-35. http://dx.doi.org/10.2308/aud.2004.23.2.13

Bommel, J. V., \& Vermaelen, T. (2003). Post-IPO capital expenditures and market feedback. Journal of Banking and Finance, 27, 275-305. http://dx.doi.org/10.1016/S0378-4266(01)00249-7

Brick, I., Palmon, O., \& Wald, J. (2005). CEO compensation, director compensation, and firm performance: Evidence of cronyism? Working paper, Rutgers University.

Bursa Malaysia Securities Berhad. (2007). Listing Requirement. Main market listing requirements. Retrieved from 
http://www.bursamalaysia.com/website/bm/regulation/rules/listing_requirements/downloads/bm_mainchapt er3.pdf

Chen, C. J. P., Chen, S., \& Su, X. (2001). Is accounting information value-relevant in the emerging Chinese stock market? Journal of International Accounting, Auditing \& Taxation, 10, 1-22. http://dx.doi.org/10.1016/S1061-9518(01)00033-7

Chen, K. C. W., \& Church, B. K. (1996). Going concern opinions and the market's reaction to bankruptcy filings. The Accounting Review, 71, 117-128.

Chia, Y. M., Lapsley, I., \& Lee, H. W. (2007). Choice of auditors and earnings management during the Asian financial crisis. Managerial Auditing Journal, $22(2), \quad$ 177-196. http://dx.doi.org/10.1108/02686900710718672

Choo, T. M., \& Peter, L. L. N. (1998). Accounting for extraordinary items in Singapore: Empirical findings and international implications. Journal of International Accounting, Auditing \& Taxation, 7(2), $215-232$. http://dx.doi.org/10.1016/S1061-9518(98)90015-5

Cotter, J. (1998). Utilisation and restrictiveness of covenants in Australian private debt contracts. Accounting and Finance, 38(2), 181-196. http://dx.doi.org/10.1111/1467-629X.00009

David-Friday, P. Y., Eng, L. L., \& Liu, C. S. (2006). The effects of the Asian crisis, corporate governance and accounting system on the valuation of book value and earnings. The International Journal of Accounting, 41(2006), 22-40. http://dx.doi.org/10.1016/j.intacc.2005.12.002

Dechow, P. M., \& Dichev, I. D. (2002). The quality of accruals and earnings: the role of accrual estimation errors. The Accounting Review, 77, 35-59. http://dx.doi.org/10.2308/accr.2002.77.s-1.35

Dechow, P. M., Sloan, R. G., \& Sweeney, A. P. (1995). Detecting earnings management. The Accounting Review, 70(2), 193-225.

Dechow, P. M., Sloan, R. G., \& Sweeney, A. P. (1996). Causes and consequences of earnings manipulation: An analysis of firms subject to enforcement actions by the SEC. Contemporary Accounting Research, 13(1), 1-36. http://dx.doi.org/10.1111/j.1911-3846.1996.tb00489.x

Dedman, E. (2000). An investigation into the determinants of UK board structure before and after Cadbury. Corporate Governance, 8, 133-153. http://dx.doi.org/10.1111/1467-8683.00191

DeFond, M., \& Jiambalvo, J. (1994). Debt covenant violation and manipulation of accruals. Journal of Accounting and Economics, 17(1-2), 145-176. http://dx.doi.org/10.1016/0165-4101(94)90008-6

Easton, P., Harris, T., \& Ohlson, J. (1992). Aggregate accounting earnings can explain most of security returns. Journal of Accounting and Economics, 15, 119-142. http://dx.doi.org/10.1016/0165-4101(92)90015-T

Fama, E., \& French, K. (2000). Forecasting profitability and earnings. Journal of Business, 73, $161-175$. http://dx.doi.org/10.1086/209638

Giroux, G. (2006). Earnings Magic and the Unbalance Sheet: The Search for Financial Reality. Wiley: US.

Godfrey, J., Hodgson, A., Holmes, S., \& Tarca, A. (2006). Accounting Theory (6th ed). Australia: John Wiley.

Godfrey, J., Hodgson, A., Tarca, A., Hamilton, J., \& Holmes, S. (2010). Accounting Theory (7th ed). Australia: John Wiley.

Gompers, P., Ishii, J., \& Metrick, A. (2003). Corporate Governance and Equity Prices. Quarterly Journal of Economics, 118(1), 107-155. http://dx.doi.org/10.1162/00335530360535162

Gul., F., \& Tsui, J. (2001). Free cash flow, debt monitoring and audit pricing: Further evidence on the role of director equity ownership. Auditing: A Journal of Practice \& Theory, 20(2), 71-84. http://dx.doi.org/10.2308/aud.2001.20.2.71

Healy, P. (1985). The effect of bonus schemes on accounting decisions. Journal of Accounting and Economics, 7(April), 85-107. http://dx.doi.org/10.1016/0165-4101(85)90029-1

Healy, P., \& Wahlen, J. (1999). A review of the earnings management literature and its implications for standard setting. Accounting Horizons, 13(4), 365-384. http://dx.doi.org/10.2308/acch.1999.13.4.365

Healy, P., Kang, S., \& Palepu, K. (1987). The effect of accounting procedure changes on CEO's cash salary and bonus compensation. Journal of Accounting and Ecnomics, 9(January), 7-34. http://dx.doi.org/10.1016/0165-4101(87)90015-2 
Hill, R. C., Griffiths, W. E., \& Judge, G. G. (2001). Undergraduate Econometrics (2nd ed). US: John Wiley.

Ho, P., \& Sia, C. S. (2007). Earnings management and stock market response: A study of Malaysian firms. Conference proceeding-19th Asian-Pacific Conference on International Accounting Issues, Malaysia (Kuala Lumpur, Nov 11-14, 2007).

Holland, D., \& Ramsay, A. (2003). Do Australian companies manage earnings to meet simple earnings benchmarks? Accounting \& Finance, 43(1), 41-62. http://dx.doi.org/10.1111/1467-629X.00082

Holthausen, R. W. (1990). Accounting Method Choice: Opportunistic Behaviour, Efficient Contracting, and Information Perspectives. Journal of Accounting and Economics, 12, 207-218. http://dx.doi.org/10.1016/0165-4101(90)90047-8

Holthausen, R. W., Larcker, D. F., \& Sloan, R. G. (1995). Annual Bonus Schemes and the Manipulation of $\begin{array}{lllll}\text { Earnings. Journal of Accounting and } & \text { Economics, } & 19, & \text { 29-74. }\end{array}$ http://dx.doi.org/10.1016/0165-4101(94)00376-G

Jaggi, B., \& Leung, S. (2007). Impact of family dominance on monitoring of earnings management by audit committees: Evidence from Hong Kong. Journal of International Accounting, Auditing and Taxation, 16, 27-50. http://dx.doi.org/ 10.1016/j.intaccaudtax.2007.01.003

Jomo, K. S. (1998). Malaysian debacle: Whose fault? Cambridge Journal of Economics, 22, 707-722. http://dx.doi.org/10.1093/cje/22.6.707

Jones, J. J. (1991). Earnings management during import relief investigations. Journal of Accounting Research, 29(2), 193-228. http://dx.doi.org/10.2307/2491047

Jones, S., \& Sharma, R. (2001). The impact of free cash flow, financial leverage and accounting regulation on earnings management in Australia's 'old' and 'new' economies. Managerial Finance, 27(12), 18-39. http://dx.doi.org/10.1108/03074350110767420

Kiel, G., \& Nicholson, G. (2003). Board composition and corporate performance: How the Australian experience informs contrasting theories of corporate governance. Corporate Governance, 11(3), 189-205. http://dx.doi.org/10.1111/1467-8683.00318

Klein, A. (2002). Audit Committee, Board of Director Characteristics, and Earnings Management. Journal of Accounting and Economics, 33(3), 375-401. http://dx.doi.org/10.1016/S0165-4101(02)00059-9

Koch, A. S. (2002). Financial distress and the credibility of management earnings forecasts. SSRN working paper.

Kothari, S. P. (2001). Capital markets research in accounting. Journal of Accounting and Economics, 31(2001), 105-231. http://dx.doi.org/10.1016/S0165-4101(01)00030-1

La Porta, R., Lopez-de-Silanes, F., Shleifer, A., \& Vishny, R. (1998). Law and finance. Journal of Political Economy, 106, 1113-1155. http://dx.doi.org/10.3386/w5661

Larcker, D. F., Richardson, S. A., \& Tuna, I. (2007). Corporate governance, accounting outcomes, and

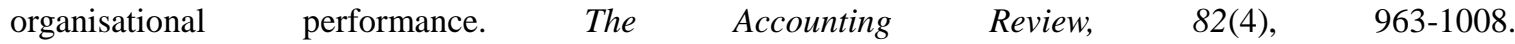
http://dx.doi.org/10.2308/accr.2007.82.4.963

Lee, T. S., \& Yeh, Y. H. (2004). Corporate governance and financial distress: Evidence from Taiwan. Corporate Governance, 12(3), 378-388. http://dx.doi.org/10.1111/j.1467-8683.2004.00379.x

Lev, B. (2003). Corporate earnings: facts and fiction. Journal of Economic Perspectives, 17(2), 27-50. http://dx.doi.org/10.1257/089533003765888412

Levitt, A. Jr. (1998). The numbers game. The CPA Journal, Accounting \& Tax Periodicals, 68(12), 14-19.

Lin, J. W., \& Hwang, M. I. (2010). Audit quality, corporate governance, and earnings management: A $\begin{array}{lllll}\text { meta-analysis. International Journal of } & \text { Auditing, } & \text { 14, }\end{array}$ http://dx.doi.org/10.1111/j.1099-1123.2009.00403.x

Lin, J. W., Li, J. F., \& Yang, J. S. (2006). The effect of audit committee performance on earnings quality. Managerial Auditing Journal, 21(9), 921-933. http://dx.doi.org/ 10.1108/02686900610705019

Maher, M., \& Anderson, T. (2000). Corporate governance: Effects on firm performance and economic growth. OECD working paper. http://dx.doi.org/10.2139/ssrn.218490

McConnell, J., \& Muscarella, C. (1985). Corporate capital expenditure decisions and the market value of the 
firm. Journal of Financial Economics, 14, 399-422. http://dx.doi.org/10.1016/0304-405X(85)90006-6

Mueller, D. C. (2006). The Anglo-Saxon Approach to Corporate Governance and its Applicability to Emerging Markets. Corporate Governance, 14(4), 207-219. http://dx.doi.org/10.1111/j.1467-8683.2006.00503.x

Opera, R. (2008). Free Cash Flow and Takeover Threats; An Experimental Study. Southern Economic Journal, 75(2), 351-366.

Owens-Jackson, L., Robinson, D., \& Shelton, S. (2009). The association between audit committee characteristics, the contracting process and fraudulent financial reporting. American Journal of Business, 24(1), 57-65. http://dx.doi.org /10.1108/19355181200900005

Peasnell, P., Pope, P., \& Young, S. (2005). Board monitoring and earnings management: Do outside directors influence abnormal accruals? Journal of Business Finance \& Accounting, 32(7-8), 1311-1346. http://dx.doi.org/10.1111/j.0306-686X.2005.00630.x

Penman, S. (2006). Financial statement analysis and security valuation (3rd ed). US: McGraw-Hill.

Radelet, S., \& Sachs J. (1998). The East Asian financial crisis: diagnosis, remedies prospects. Brookings Papers on Economic Activity, 1(1), 1-90. Harvard Institute for International Development. http://dx.doi.org/10.2307/2534670

Richardson, S. (2006). Over-investment of free cash flow. Review of Accounting Studies, 11, 159-189. http://dx.doi.org/10.1007/s11142-006-9012-1

Richardson, S., Sloan, R. G., Soliman, M., \& Tuna, I. (2005). Accrual reliability, earnings persistence and stock prices. Journal of Accounting and Economics, 39, 437-485. http://dx.doi.org/10.1016/j.jacceco.2005.04.005

Ryan, H. Jr., \& Wiggins, R. III. (2004). Who is in whose pocket? Director compensation, board independence, and barriers to effective monitoring. Journal of Financial Economics, 73, 497-524. http://dx.doi.org/10.1016/j.jfineco.2003.11.002

Schilit, H. M. (2002). Financial shenanigans: how to detect accounting gimmicks \& fraud in financial reports (2nd ed). New York: McGraw-Hill.

Shamsher, M., \& Taufiq, H. C. (2002). Financial Failures: Any Lessons Please?. The Journal of Chartered Secretaries Australia, 54(7), 392-396.

Shamsul, N. A. (2004). Board composition, CEO duality and performance among Malaysian listed companies. Corporate Governance, 4(4), 47-61. http://dx.doi.org/10.1108/14720700410558871

Sloan, R. (1996). Do stock prices fully reflect information in accruals and cash flows about future earnings. The Accounting Review, 71(3), 289-315.

Star Bizweek. (2004). Spotlight on PN4 companies by Errol Oh. The Star Bizweek, May 8, 2004, pp. 10-11.

Sweeney, A. (1994). Debt-covenant violations and managers' accounting responses. Journal of Accounting and Economics, 17(3), 281-308. http://dx.doi.org/10.1016/0165-4101(94)90030-2

Titman, S., Wei, K. C., \& Xie, F. (2003). Capital investments and stocks returns. Working paper - National Bureau of Economic Research.

Turley, S., \& Zaman, M. (2004). The corporate governance effects of audit committees. Journal of Management and Governance, 8, 305-332. http://dx.doi.org/10.1007/s10997-004-1110-5

Velez-Pareja, I. (2010). Back to basics: Cost of capital depends on free cash flow. The IUP Journal of Applied Finance, 16(1), 27-39.

Wang, J. Y. (2001). Liquidity management, operating performance, and corporate value: Evidence from Japan and Taiwan. Journal of Multinational Financial Management, 12, 159-169. http://dx.doi.org/10.1016/S1042-444X(01)00047-0

Watts, R., \& Zimmerman, J. (1978). Towards a positive theory of the determination of accounting standards. The Accounting Review, 53, 112-134.

Watts, R., \& Zimmerman, J. (1990). Positive Accounting Theory: A Ten Year Perspective. The Accounting Review, 65(1), 131-156.

Whelan, C., \& McNamara, R. (2004). The impact of earnings management on the Value-relevance of financial statement information. Working paper, Georgia College \& State University, USA. http://dx.doi.org/10.2139/ssrn.585704 
Whitaker, R. B. (1999). The Early Stages of Financial Distress. Journal of Economics and Finance, 23(2), 123-133. http://dx.doi.org/10.1007/BF02745946

White, H. (1980). A Heteroskedasticity-Consistent Covariance Matrix Estimator and a Direct Test for Heteroskedasticity. Econometrica, 48(4), 817-838. http://dx.doi.org/10.2307/1912934

Wild, J. (1996). The audit committee and earnings quality. Journal of Accounting, Auditing and Finance, 11, 247-276. http://dx.doi.org/10.1177/0148558X9601100206

Woolridge, J. R., \& Snow, C. C. (1990). Stock market reaction to strategic investment decisions. Strategic Management Journal, 11, 353-363. http://dx.doi.org/10.1002/smj.4250110503

Xie, B., Davidson III, W. N., \& DaDalt, P. J. (2003). Earnings management and corporate governance: The role of the board and the audit committee. Journal of Corporate Finance, 9, 295-316. http://dx.doi.org/10.1016/S0929-1199(02)00006-8

Xing, Y. (2002). Firm investments and expected equity returns. Working paper - Rice University.

\section{Notes}

Note 1. For instance, the increase of opportunistic discretional adjustments can be witnessed from the increased level of nonrecurring items included in total firms' earnings (e.g., Choo \& Peter, 1998; Healy, 1985).

Note 2. In some anecdotal studies, accounting researchers connect firms' accounting metrics reliability or quality to the persistency of the earnings (e.g., Penman, 2006, Richardson et al., 2005, Wang, 2001). The concept of persistency is well summarised by Penman (2006) as 'earnings that are indicative of firm's long-run earnings ability are called sustainable earnings, persistent earnings or core earnings. Earnings based on temporary factors are called unusual earnings or transitory earnings.' (p. 409).

Note 3. The size hypothesis predicts that the larger the firm size, the more conservative are the firm's accounting policy choices, and thus the higher the earnings reliability.

Note 4 . These two variables are expected to positively correlate to earnings reliability.

Note 5. Industry sectors are clustered based on Bursa Malaysia main board and second board listing classifications.

Note 6. Specifically, earnings induced by accounting policy choices always reverse in the subsequent fiscal period and thus are of poor quality.

Note 7. Negative abnormal earnings are converted to one direction to denote discretionary earnings deflation due to potential manipulation.

Note 8. The frequency of firms issuing ESOS to employees is comparatively low to the total number of firm-year observations. In a total of 4845 firm-year observations, only 1595 observations with ESOS are documented (about 32.9\%).

Note 9. The descriptive statistics in Table 3-1 show that the mean of $\operatorname{ESOS}_{\mathrm{j}, \mathrm{t}}$ is 0.013 , indicating that ESOS represents only about $1.3 \%$ of firms' total paid-up capital in overall.

Note 10. However, the results from the multivariate analysis on $\operatorname{OWNCON}_{\mathrm{j}, \mathrm{t}}\left(\beta_{7}=0.010, \mathrm{p}=0.275\right)$ and OWNMN $_{\mathrm{j}, \mathrm{t}}\left(\beta_{8}=-0.003, \mathrm{p}=0.413\right)$ are insignificant. These observations are possibly due to the over-fitting effect by other more dominant attributes which causes epistemic uncertainty in the econometric model (Hill et al., 2001).

Note 11. AUCOMIN $\mathrm{j}_{\mathrm{j}, \mathrm{t}}$ is significant to earnings reliability in the multivariate test $\left(\beta_{11}=-0.030, \mathrm{p}=0.035\right)$, the direction of the relationship is however counter-intuitive.

\section{Copyrights}

Copyright for this article is retained by the author(s), with first publication rights granted to the journal.

This is an open-access article distributed under the terms and conditions of the Creative Commons Attribution license (http://creativecommons.org/licenses/by/3.0/). 